\title{
Discarding of plaice (Pleuronectes platessa) in the Danish North Sea trawl fishery
}

\author{
Madsen, Niels; Feekings, Jordan P.; Lewy, Peter
}

Published in:

Journal of Sea Research

Link to article, DOI:

10.1016/j.seares.2012.05.005

Publication date:

2013

Link back to DTU Orbit

Citation (APA):

Madsen, N., Feekings, J. P., \& Lewy, P. (2013). Discarding of plaice (Pleuronectes platessa) in the Danish North Sea trawl fishery. Journal of Sea Research, 75, 129-134. https://doi.org/10.1016/j.seares.2012.05.005

\section{General rights}

Copyright and moral rights for the publications made accessible in the public portal are retained by the authors and/or other copyright owners and it is a condition of accessing publications that users recognise and abide by the legal requirements associated with these rights.

- Users may download and print one copy of any publication from the public portal for the purpose of private study or research.

- You may not further distribute the material or use it for any profit-making activity or commercial gain

- You may freely distribute the URL identifying the publication in the public portal

If you believe that this document breaches copyright please contact us providing details, and we will remove access to the work immediately and investigate your claim 


\title{
Journal of Sea Research
}

http://dx.doi.org.globalproxy.cvt.dk/10.1016/i.seares.2012.05.005

Copyright (C) 2012 Elsevier B.V. All rights reserved.
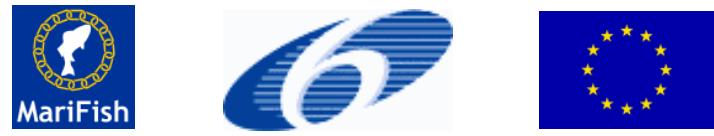

DTU Aqua

National Institute of Aquatic Resources

http://www.marifish.net/

http://www.aqua.dtu.dk

\section{Discarding of plaice (Pleuronectes platessa) in the Danish North Sea trawl fishery}

\author{
Niels Madsen*, Jordan Feekings, Peter Lewy \\ DTU Aqua, National Institute of Aquatic Resources, North Sea Science Park, DK-9850 Hirtshals, \\ Denmark
}

\begin{abstract}
Plaice (Pleuronectes platessa) play an important role in the North Sea benthic ecosystem and is by weight the most important commercial flatfish species in the North Sea demersal fishery. There is a high discarding of plaice in the active demersal fisheries in the North Sea. The change in fisheries management towards a more ecosystem based approach, together with a greater focus on sustainability, has caused a severe need for action. Subsequently, the European Commission is preparing regulations to reduce or even ban discards. The trawl fisheries are commercially the most important Danish fishery targeting plaice. Here we analyse discard data collected onboard Danish vessels in the period from 1998 to 2008. We describe the general patterns in these data by dividing them into three mesh size categories: $80-99 \mathrm{~mm}, 100-119 \mathrm{~mm}$ and $\geq 120 \mathrm{~mm}$ to reflect implemented technical measures of relevance. We analyse the landed and discarded portions in these mesh size categories and link the discarding to the minimum landing size. We employed a GAM model to assess how discarding of plaice below the minimum landing size is connected to relevant factors that could be of relevance from a management perspective. We identified a statistical significant effect of mesh size category and area. We discuss the results in relation to potential mitigation measures to be implemented in future fisheries management strategies.
\end{abstract}

Keywords: Discards; Fisheries management; North Sea; Pleuronectes platessa; Plaice; Trawl

*Corresponding author: $\underline{\text { nm@aqua.dtu.dk }}$

Article first published online: Jan 2013

Please note that this is an author-produced PostPrint of the final peer-review corrected article accepted for publication. The definitive publisher-authenticated version can be accesses here:

http://dx.doi.org.globalproxy.cvt.dk/10.1016/i.seares.2012.05.005 


\title{
Discarding of plaice (Pleuronectes platessa) in the Danish
}

\section{North Sea trawl fishery}

\author{
Niels Madsen*1, Jordan Feekings ${ }^{1}$, Peter Lewy \\ DTU Aqua, National Institute of Aquatic Resources, North Sea Science Park, DK-9850 Hirtshals, \\ Denmark \\ *Corresponding author. Tel.: +45-33963200; Fax: + 45-33963260; E-mail address: \\ nm@aqua.dtu.dk (Niels Madsen) \\ ${ }^{1}$ Authorship equal
}

\begin{abstract}
\end{abstract}
Plaice (Pleuronectes platessa) play an important role in the North Sea benthic ecosystem and is by weight the most important commercial flatfish species in the North Sea demersal fishery. There is a high discarding of plaice in the active demersal fisheries in the North Sea. The change in fisheries management towards a more ecosystem based approach, together with a greater focus on sustainability, has caused a severe need for action. Subsequently, the European Commission is preparing regulations to reduce or even ban discards. The trawl fisheries are commercially the most important Danish fishery targeting plaice. Here we analyse discard data collected onboard Danish vessels in the period from 1998 to 2008 . We describe the general patterns in these data by dividing 
them into three mesh size categories: $80-99 \mathrm{~mm}, 100-119 \mathrm{~mm}$ and $\geq 120 \mathrm{~mm}$ to reflect implemented technical measures of relevance. We analyse the landed and discarded portions in these mesh size categories and link the discarding to the minimum landing size. We employed a GAM model to assess how discarding of plaice below the minimum landing size is connected to relevant factors that could be of relevance from a management perspective. We identified a statistical significant effect of mesh size category and area. We discuss the results in relation to potential mitigation measures to be implemented in future fisheries management strategies.

Keywords: Discards; Fisheries management; North Sea; Pleuronectes platessa; Plaice; Trawl

\section{Introduction}

Plaice play an important role in the North Sea benthic ecosystem, being one of the most abundant flatfish species and one of the most important species for the fishery (Sparholt, 1990; Daan et al., 1990; ICES, 2008). Nevertheless, the plaice fishery in the North Sea is characterized by a high discard rate, approximately $50 \%$ by weight of the catches (ICES, 2011). High mortality of discarded plaice (50-100\%) is indicated from both beam trawls (Van Beek et. al., 1990; Kaiser and Spencer, 1995) and trawls (Evans et al., 1994; Millner et al., 1993). Discard survival will likely depend on several factors like the fishing gear, fish and fishing conditions and an additional mortality caused by sea bird predation (Hudson and Furness, 1988; Evans et al., 1994; Garthe and Hüppop, 1994; Votier et al., 2004). Consequently, measures to reduce the amount of plaice discarded in the North Sea fisheries would greatly benefit the stock (ICES, 2011) and reduce the anthropogenic impact on the marine ecosystem. The reduction of discards is also a main issue in the 
2012 revision of the European Common Fisheries Policy and a key aspect in voluntary certification of fisheries (Marine Stewardship Council, www.msc.org).

Several technical measures have been applied in the North Sea to reduce the fishing mortality on juvenile plaice. Of relevance for active demersal gears are mesh size regulations, a partially closed area (the plaice box) and a minimum landing size. The closed area (plaice box) is placed along the continental coast where vessels lager than $300 \mathrm{HP}$ have not been allowed to fish since 1995 in an attempt to reduce discards of juvenile plaice (Pastoors et al., 2000; Van Keeken et al., 2007) that are concentrated in this area (Rijnsdorp and Pastoors, 1995; Pastoors et al., 2000; Van Keeken et al., 2007). There has not been proven any clear effect on the stock (Pastoors et al., 2000; ICES, 2011) but it is likely that this will increase survival of juvenile plaice. There are several mesh size regulations in force, and today the use of meshes $80-99 \mathrm{~mm}$ is only allowed in the southern North Sea (South of $55^{\circ} \mathrm{N}$ or $56^{\circ} \mathrm{N}$ east of $5^{\circ} \mathrm{E}$ ) whereas the minimum mesh size in the North is $100 \mathrm{~mm}$ (ICES, 2011). Recent estimates on the selectivity of plaice in trawls have been made (Frandsen et al., 2009; Frandsen et al., 2010; Frandsen et al., 2011) making it possible to assess the selectivity in relation to discard mitigation measures.

Discarding of plaice is recognized as a major management problem and several aspects of plaice discarding in the North Sea have been assessed (Van Beek et al., 1990; Evans et al., 1994; Berghahn, 1998; Dickey-Collas, 2007; Aarts and Poos, 2009; Poos et al., 2009; Depestele et al., 2011). There is, nevertheless, a lack of publications that analyse and describe the general discard pattern of plaice in the North Sea trawl fishery with focus on potential mitigation measures. A particular reason is that discard sampling programs are often expensive and require a large number of man hours, while providing data which are spare in relation to the total effort in a given fishery (Dickey-Collas et al., 2007; Aarts and Poos, 2009). However, discard analyses are of importance for inclusion in stock assessment and the associated management advice (Dickey-Collas et al., 2007). 
Several technical measures have been implemented over the years, however, the level of discarding remains high (ICES, 2011). Therefore, evaluating factors that can be used by managers to reduce discard amounts and rates is of importance. Discard reduction is also an important facet of the long term management plan implemented in 2008, aiming at having the stock within safe biological limits (ICES, 2010). Trawls are the most important fishing gear targeting plaice in the Danish North Sea fishery. Discard data from the Danish fishery have been collected since the nineties. This provides the possibility to assess discarding for a relatively large number of hauls. Here we analyse discard data collected from the Danish demersal trawl fishery in the North Sea in the period from 1998 to 2008 . The main aim is to analyse the discard data with particular focus on factors that could be important for management strategies in the future.

\section{Methodology}

\subsection{Discard Sampling}

Danish discard data was originally collected under a national programme and later (2002) in accordance with the European Data Directive (1639/2001). Data sampling is stratified with regards to: ICES sub-division, quarter, and defined by mesh size categories. Sampling is carried out on board commercial vessels voluntarily participating in the discard sampling programme. The observer has no relation to the control units, whereby it is assumed that the fishing practice is unaffected by his presence. The vessels and trips are chosen to be representative of all important fishing harbours, the entire period, all vessel sizes and all durations of trips in the given fishery. The criteria for hauls included in this analysis are that they are conducted in the North Sea with demersal trawls in the period from 1998 to 2008 with a mesh size of $80 \mathrm{~mm}$ or larger. The trawls 
are fished in single or multiple rigs often from a single vessel, but in a few cases pair trawling is recorded (trawls towed by two vessels). These fisheries are generally defined by being mixed fisheries targeting species for human consumption. The fishery is complex, having fluctuating catch compositions and targeting a wide range of species.

\subsection{Relevant factors}

Many social (Catchpole et al., 2005; Rochet and Trenkel, 2005), technical (Stratoudakis et al., 2001; Rochet and Trenkel, 2005) as well as environmental (Catchpole et al., 2005; Rochet and Trenkel, 2005) factors can be considered as having a potential effect on discards. However, this analysis is focussed on variables that are relevant for management of the fishery because they are directly controllable. Factors considered include geographical area, season (quarter) and mesh size category (defined by mesh size intervals). The discard rate could be largely positively correlated with juvenile abundance. Although this is not controllable by managers it has the potential to distort the effect of other influential factors such as mesh size and was therefore also considered. We considered the size spectrum from the minimum retention length up to the MLS by using recruitment data for age classes one and two from the official assessment (ICES, 2010). We assessed juvenile abundance by year and quarter, assuming mortality (natural and fishing mortality) to be constant throughout the year. Year classes one and two were assessed separately and also their effects combined.

We defined haul location as the midpoint in the tows (straight line between start and end). To increase the number of observations for each time period we used quarter (start $1^{\text {st }}$ January) rather than month. Since mesh size will influence the selectivity in the gears, it is considered to be a main factor affecting the discarding of plaice (Van Keeken et al., 2007; ICES, 2011). We divided mesh 
size into three main categories: $80-99 \mathrm{~mm} ; 100-119 \mathrm{~mm}$ and $\geq 120 \mathrm{~mm}$ (largest observed size is 127 $\mathrm{mm}$ ), reflecting the regulations. These include minimum mesh sizes of $80 \mathrm{~mm}$ in the southern North Sea, $100 \mathrm{~mm}$ in the northern North Sea and $120 \mathrm{~mm}$ for the whitefish fishery in the northern North Sea. This division also ensures a reasonable number of observations per mesh size category. The conventional mesh size is noted by the discard observers but is not necessarily measured. Since mesh size regulations have changed over the years, some of the discard observations are not in line with current legislation, having smaller mesh sizes than allowed in the area today. The mesh sizes are reported to be somewhat larger (around $5 \mathrm{~mm}$ ) than the minimum allowed. This is to avoid potential conflict with the legislation, since the size of the mesh can decrease over time. It is rarely that the conventional mesh size is below the minimum allowed. The use of selective devices is not well documented in the discard data. However, square mesh panels have been implemented in legislation in some fisheries during the study period. These panels are inserted with the objective of improving the selectivity of gadoids, particularly cod, and do not fit well to the morphology of plaice. Subsequently, they are not expected to influence the selectivity of plaice (Madsen et al., 2006; Frandsen et al., 2010) since the minimum allowed mesh sizes in the square mesh panels are not substantially higher than that used in the rest of the codend. A minimum landing size (MLS) of $27 \mathrm{~cm}$ is effective for the whole investigated period.

Since a mismatch between mesh size and MLS is likely to be influential on discard rates we used recently published data on plaice selectivity in trawls (Frandsen et al., 2009; Frandsen et al., 2010; Frandsen et al., 2011) to assess this relationship further. We estimated mean values from 4 experiments assuming the selection factor (L50 (50\% retention length)/mesh size) and also the selection ratio (selection range ( $75 \%$ retention length $-25 \%$ retention length)/L50) to be constant. This is because the selection range can increase with L50 and hence mesh size (Madsen, 2007). The 
average selection factor was estimated to 2.15 (range 2.04-2.28) and the average selection ratio to 0.146 (range $0.108-0.182$ ).

\subsection{Comparisons of mean values}

Mean values for each mesh size category were estimated for discards and landings (no./hour), discard proportions (no.) and lengths (cm) of discards and landings. To conduct a more detailed analysis of discarding mean values in relation to MLS the total proportion below MLS, two length intervals just below MLS (23-24 cm and 25-26 cm) and a length interval just above MLS (27-28 $\mathrm{cm}$ ) were estimated. All mean values were compared pair-wise by a two-sample t-test. In principles, this requires that the mean values approximately follow normal distributions. The observations are not normally distributed particularly because most cases include zero discard observations. However, the positive observations exceed the zero's in most cases. It was examined by bootstrap if the mean values approximately follow a normal distribution. This was done for each set of observations as follows: 1) draw a random sample of the observations with replacement; 2) calculate the mean; repeat step 1 and 2 10,000 times; draw a histogram and a qq plot of the 10,000 simulated means. The plots indicate that the normal approximations seem reasonable. The applicability of the t-test is further justified by Sullivan and D'Agostino (1992), even in cases with up to $50 \%$ zero observations.

\subsection{Modelling discarded numbers under MLS}

To describe the main reasons for discarding that are relevant to management we modelled discarded numbers under MLS per haul as the response variable. However, as haul durations differ 
per observation we may simply measure a large number of discards because the haul duration was long. To account for this we used log haul duration as an offset term, whereby the fitted values are always positive, the confidence intervals around the fitted values do not contain negative values, and we allow for heterogeneity (Zuur et al., 2009). To account for the unbalanced sampling design between explanatory variables, and describe the main spatial distribution, generalized additive models (i.e. GAMs, Hastie and Tibshirani, 1990) were used with the assumption of an underlying binomial distribution (log link). A negative binomial distribution was chosen a priori seeing as the data are counts without an upper limit, and overdispersed (i.e. variance exceeds the mean or contain a large number of zero observations). The full model was formulated as follows:

Numbers discarded under MLS per haul $=$ mesh size category $+s($ longitude, latitude $)+$ quarter + $s($ juvenile abundance $)+$ offset(log haul duration $)+\varepsilon$

where $s$ is an isotropic smoothing function (thin-plate regression spline), and $\varepsilon$ is an error term.

Covariates included in the initial model were removed one at a time until all covariates were significant $(P<0.05)$. To simplify the interpretation of the interaction between longitude and latitude, the maximum degrees of freedom (measured as number of knots $\mathrm{k}$ ) allowed to the smoothing function was limited to $\mathrm{k}=20$. To check for violation of independence within the spatial term variograms of the residuals were used (Zuur et al., 2009). No spatial correlation was present in any of the models fitted. The analysis was performed using R software, a statistical environment for computation and graphics (http://www.r-project.org).

\section{Results}


General information on the discard sampling data is provided in Table 1. Fewest years are covered by the $80-99 \mathrm{~mm}$ mesh size category where there are data from 2001-2005, whereas the 100-119 mm mesh size category has data from 1998-2002, 2004 and 2007. Most years are covered by the $\geq 120 \mathrm{~mm}$ mesh size category which covers the years 1998, 2002-2008. The mean horsepower increases with the mesh size (Table 1). The mean haul duration is highest for the 80-99 $\mathrm{mm}$ mesh size category (Table 1). The highest numbers of hauls were recorded for the $\geq 120 \mathrm{~mm}$ category. The relative proportion of hauls having discard observations decreases with increasing mesh size. There is about the same amount of hauls with landings and discards in the two smallest mesh size categories but a higher number of landings than discards in largest mesh size category. Landings have not been length measured in all hauls (only total landings weight recorded in 15 hauls) for the 100-119 mm mesh size category (Table 1).

The geographical distribution of the observations is indicated in Fig. 1. There is some difference in the spatial distributions of the mesh size categories. The $80-99 \mathrm{~mm}$ mesh size category was located mainly in a narrow area in the central North Sea, while the $\geq 120 \mathrm{~mm}$ mesh size category was more widely distributed with more observations in the northern parts of the North Sea. Means for different discard and landings categories, together with their 95\% confidence intervals and significance levels from the comparisons of the three mesh size categories (t-test) are presented in Table 2. The mean discard rate, in numbers per hour, in the $\geq 120 \mathrm{~mm}$ mesh size category was approximately a factor of 10 and a factor of 30 lower than in the 100-119 mm and 80-99 mm mesh size categories respectively. Differences are statistically different between all mesh size categories. No statistically significant differences were observed in mean landings (numbers) per hour for the three mesh size categories. Mean discard proportions are statistical significantly different for all categories. The mean length of discarded plaice increases significantly with increasing mesh size category. The main part of the discarding is below MLS for all categories, but lowest in the $\geq 120$ 
mm category, having $69 \%$ of the discards below MLS. In total, more than half of the discards are in the size range $23-26 \mathrm{~cm}$, with the main part being in the $25-26 \mathrm{~cm}$ interval just below MLS. The discarded proportion in the $27-28 \mathrm{~cm}$ interval, just above MLS, is lowest in the 80-99 $\mathrm{mm}$ and 100$119 \mathrm{~mm}$ mesh size categories while highest in the $\geq 120 \mathrm{~mm}$ mesh size category.

Selection curves indicating the selectivity of 80, 100 and $120 \mathrm{~mm}$ mesh sizes are shown in Fig. 2 together with the MLS. The retention of plaice at MLS (27 cm) for the three mesh sizes are 100\%, $98 \%$ and $67 \%$ respectively, indicating a mismatch also for the $120 \mathrm{~mm}$ mesh size. The $10 \%$ retention lengths are 15,16 and $22 \mathrm{~cm}$ respectively.

The correlation between juvenile abundance and discards under MLS was found to be negative in the GAM model. Inspection indicated that this was probably caused by the structure of the data. A low number of observations were recorded in years with high juvenile abundance. These also corresponded to the largest mesh size category. Having no significant positive correlation, juvenile abundance was excluded from the analysis. Quarter was found to be non-significant and removed from the final model. Significant variables in the final model are presented in Table 3. The discard rates in the $\geq 120 \mathrm{~mm}$ and $100-119 \mathrm{~mm}$ mesh size categories were significantly lower than the $80-99$ $\mathrm{mm}$ mesh size category. However, the difference between the $100-119 \mathrm{~mm}$ and $\geq 120 \mathrm{~mm}$ mesh size categories was non-significant. The interaction between longitude and latitude on discard rates was also found to be highly significant (Table 3, Fig. 3). Discarding is highest in the area closest to the plaice box in the south east and decreases with increasing distance. The proportion of null deviance explained by the final model was $85.3 \%$.

\section{Discussion}


This is the first detailed study of the general discarding pattern of plaice in the North Sea trawl fishery (but see Poos et al., 2012). There are some clear patterns of importance for the future management strategy. The discard data analysed here are not collected by random sampling since it is stratified and representative under certain criteria. The data used covers a very limited amount of the relevant fishery $(<1 \%)$ and there is not a complete overlap in the data of the three mesh size categories concerning time and area. Some of this is accounted for in the modelling by including some important variables, but there might be other influential variables, for example, ecological factors (Pastoors et al., 2000), that are not fully accounted for in this study. Although there was no effect of increasing discard rates with high year class strengths of juvenile plaice more detailed recruitment data and discard data in time and space are needed to assess this in further detail. The indication of a clear area effect is in agreement with the expectation of a high number of younger plaice closer to the nursery grounds (Rijnsdorp and Pastoors, 1995, Van Keeken et al., 2007) and the plaice box. This also suggest that discard mitigation measures for plaice are more important the closer the fishery is conducted to the plaice box.

The present analysis suggests that mesh size is highly influential on the amounts and rates of plaice discarded. The discarded proportion of the catch for the 80-99 $\mathrm{mm}$ mesh size category is in the same order of magnitude as observed in the management of plaice today (ICES, 2011) which is mainly caused by the $80 \mathrm{~mm}$ beam trawl fishery in the southern North Sea. Van Beek et al., (1981) estimated a selection factor of 2.1 in beam trawls, which is close to the selection factor we used (2.15), suggesting that the selectivity in beam trawls and otterboard trawls are comparable. More recent selectivity estimates from beam trawls would, however, be valuable.

The demonstrated mismatch between MLS and gear selectivity describes the discards even when using $120 \mathrm{~mm}$ mesh size. A MLS that corresponds to $25 \%$ retention has been mentioned as a management objective (Reeves et al., 1992). This would equal a mesh size of $135 \mathrm{~mm}$ (using 
selection estimates presented in the results section) but still causes discarding, suggesting that it is also relevant to consider the MLS. The present analysis suggests that lowering the MLS by $2 \mathrm{~cm}$ would reduce about half of the discards in the $\geq 120 \mathrm{~mm}$ mesh size category, whereas $4 \mathrm{~cm}$ could potentially reduce discards by $54-86 \%$ for the three mesh size categories. An increase in the selectivity clearly reduces the discard level. However, efficient species selective devices are needed to retain commercial species like sole and Norway lobster that are relatively smaller than plaice. Recent experiments suggest that some devices are efficient in releasing plaice in Norway lobster directed fisheries (Madsen et al., 2010) and pulse trawls might be able to increase catchability and selectivity of sole (ICES, 2011). The dynamics and complexity of the mixed fishery (Rijnsdorp et al., 2007; Andersen et al., 2010) where plaice is mainly targeted, as in the Danish fishery, makes the potential effect of an increase in selectivity more unpredictable in economic terms. However, this effect may be less consequential seeing as the fishery is dependent on many species. The length at first maturity is $20-24 \mathrm{~cm}$ in males and $30-35 \mathrm{~cm}$ in females (Van Keeken et al., 2007). Therefore, changing the fishing strategy by lowering the MLS could increase fishing mortality in areas with more small plaice and could reduce the spawning stock, particularly for females.

The majority of the North Sea Danish trawlers in the fishery for human consumption species fish with meshes $\geq 120 \mathrm{~mm}$. While this fishery has a relatively low discard rate of plaice, a considerable portion is comprised of individuals over MLS. This is most likely a result of catch restrictions causing additional discards. Also, the higher proportion of plaice discarded just above MLS could potentially be a symptom of imprecise sorting (by eye) that could be solved. The plaice landings in the $\geq 120 \mathrm{~mm}$ mesh size category suggest that it is possible to substantially reduce discarding without reducing landings at the same time. With very few additional means it would be possible to eliminate the discarding of plaice in the $\geq 120 \mathrm{~mm}$ fishery in accordance with the direction of future fisheries policy. Abandoning a MLS and avoiding fishing without having sufficient possibility to 
land plaice (eg. quota) seems to be a realistic option, especially if the goal is to eliminate discards completely. In this respect, there are considerable prospects in using new technology like electronic monitoring (Kindt-Larsen et al., 2011), that will make it possible to change from landings to total catch quotas and hence support new strategies for fisheries managers and give fishers the incentive to avoid discarding part of their catch.

From an isolated fisheries management point of view, a reduction in high discard rates would be expected to benefit the stock considerably. A more holistic approach should take into consideration the general ecosystem effects (Botsford et al., 1997; Jennings, 2005; Greenstreet and Rogers, 2006). Since discards are an additional food resource for opportunistic benthic scavengers (Groenewold and Fonds, 2000) and sea birds (Hudson and Furness, 1988; Evans et al., 1994; Garthe and Hüppop, 1994; Votier et al., 2004), their removal from the system may disrupt the dynamics in other parts of the marine ecosystem.

\section{Acknowledgement}

Thanks are due to the observers that collected the data, fishermen and the Danish fishermen organisation, Helle Andersen helping extracting data from databases and Valerio Bartolino for helping with R-coding. This work was conducted as part of the BADMINTON project (Bycatch And Discards: Management INdicators, Trends and location), which was carried out with the financial support of the European Union and Danish Ministry of Food, Agriculture, and Fisheries. We appreciate the comments from people reading this manuscript.

\section{References}


Aarts, G., Poos, J.J., 2009. Comprehensive discard reconstruction and abundance estimation using flexible selectivity functions. ICES J. Mar. Sci. 66, 763-771.

Andersen, B.S., Vermard, Y., Ulrich C., Hutton, T., Poos, J-J, 2010. Challenges in integrating shortterm behaviour in a mixed-fishery Management Strategies Evaluation frame: A case study of the North Sea flatfish fishery. Fish. Res. 102, 26-40.

Berghahn, R., Purps, M, 1998. Impact of discard mortality in Crangon fisheries on year-class strength of North Sea flatfish species. J. Sea Res. 40, 83-91.

Botsford, L. W., Castilla, J. C., Peterson, C. H., 1997. The Management of Fisheries and Marine Ecosystems. Science 277, 509-515.

Catchpole, T. L., Frid, C. L. J., Gray, T. S., 2005. Discarding in the English north-east coast Nephrops norvegicus fishery: the role of social and environmental factors. Fish. Res. 72, 45-54.

Daan N., Bromley, P.J., Hislop, J.R.G., Nielsen, N.A., 1990. Ecology of North Sea fish. Neth. J. Sea Res. 26, 343-386.

Depestele, J., Vandemaele, S., Vanhee, W., Polet, H., Torreele, E., Leirs, H., Vincx, M., 2011. Quantifying causes of discard variability: An indispensable assistance to discard estimation and a paramount need for policy measures. ICES J. Mar. Sci. 63, 1086-1095.

Dickey-Collas, M., Pastoors, M.A., Van Keeken, O., 2007. Precisely wrong or vaguely right: simulations of noisy discard data and trends in fishing effort being included in the stock assessment of North Sea plaice. ICES. J. Mar. Sci. 2007, 1641-1649.

Evans, S.M., Hunter, J.E., Elizal, Wahju, R.I., 1994. Composition and fate of the catch and bycatch in the Farne Deep (North Sea) Nephrops fishery. ICES J. Mar. Sci. 51, 155-168.

Frandsen, R.P., Holst, R., Madsen, N, 2009. Evaluation of three levels of selective devices relevant to management of the Danish Kattegat-Skagerrak Nephrops fishery. Fish. Res. 97, 243-252. 
Frandsen, R.P., Madsen, N., Krag, L.A., 2010. Selectivity and escapement behaviour of five commercial species in a square mesh and a diamond mesh codend. ICES. J. Mar. Sci. 67, 17211731.

Frandsen, R., Herrmann, B., Madsen, N., Krag, L. A., 2011. Development of a codend concept to improve size selectivity of Nephrops (Nephrops norvegicus) in a multi-species fishery. Fish. Res. $111,116-126$.

Garthe, S., Hüppop, O., 1994. Distribution of ship-following seabirds and their utilization of discards in the North Sea in the summer. Mar. Ecol. Prog. Ser. vol 106, 1-9.

Greenstreet, S. P. R., Rogers, S. I., 2006. Indicators of the health of the North Sea fish community: identifying reference levels for an ecosystem approach to management. ICES J. Mar. Sci. 63, 573593.

Groenewold, S., Fonds, M., 2000. Effects on benthic scavengers of discards and damaged benthos produced by the beam-trawl fishery in the southern North Sea. ICES J. Mar. Sci. 57, 1395-1406. Hastie, T.J., Tibshirani, R.J., 1990. Generalized additive models. Chapman \& Hall, London Hudson, A.V., Furness, R.W., 1988. Utilization of discarded fish by scavenging seabirds behind whitefish trawlers in Shetland. J. Zool. Lond. 215, 151-166.

ICES, 2008. ICES Advice 2008, Book 6.

ICES, 2010. Report of the Working Group on the Assessment of Demersal Stocks in the North Sea and Skagerrak (WGNSSK), 5 -11 May 2010, ICES Headquarters, Copenhagen. ICES CM 2010/ACOM:13. 1058 pp.

ICES, 2011. Advice 2011, Book 6.

Jennings, S., 2005. Indicators to support an ecosystem approach to fisheries. Fish and Fisheries 6. $212-232$ 
Kaiser, M.J., Spencer B.E., 1995. Survival of by-catch from a beam trawl. Mar. Ecol. Prog. Ser. $126,31-38$.

Kindt-Larsen, L., Kirkegaard, E., Dalskov, J., 2011. Fully documented fishery: a tool to support a catch quota management system. ICES. J. Mar. Sci. 68, 1606-1610.

Madsen, N., 2007. Selectivity of fishing gears used in the Baltic Sea cod fishery. Rev. Fish. Biol. Fish. 17, 517-544.

Madsen, N. , Frandsen, R.P., Holst, R., Krag, L.A., 2010. Development of new concepts for escape windows to minimise cod catches in Norway lobster fisheries. Fish. Res. 103, 25-29.

Madsen, N., Tschernij, V., Hansen, K., Larsson, P.O., 2006. Development and testing of a speciesselective flatfish otter trawl to reduce cod bycatches. Fish. Res. 78, 298-308.

Millner, R.S., Whiting, C.L., Howlet, G.J., 1993. Estimation of discard mortality of plaice from small otter trawlers using tagging and cage survival studies. ICES CM 1993/G:24.

Pastoors, M. A., Rijnsdorp, A. D., Beek V. F. A., 2000. Effects of a partially closed area in the North Sea ("plaice box") on stock development of plaice. ICES J. Mar. Sci. 57, 1014-1022.

Poos, J.J., Bogaards, J.A., Quirijns, F.J., Gillis, D.M., Rijnsdorp, A.D., 2010. Individual quotas, fishing effort allocation, and over-quota discarding in mixed fisheries. ICES J. Mar. Sci. 67, 323333.

Poos, J.J., Aarts, G., Vandemaele, S., Willems, W., Bolle, L.J., van Helmond, A. T. M., 2012. Estimating spatial and temporal variability of juvenile North Sea plaice from opportunistic data. J. Sea Res. This volume.

Reeves, S.A., Armstrong, D.W., Fryer, R.J., Coull, K.A., 1992. The effects of mesh size, cod-end extension length and cod-end diameter on the selectivity of Scottish trawls and seines. ICES J. Mar. Sci. 49, 279-288. 
Rijnsdorp, A. D., Pastoors, M. A., 1995. Modelling the spatial dynamics and fisheries of North Sea plaice (Pleuronectes platessa L.) based on tagging data. ICES J. Mar. Sci. 52, 963-980.

Rijnsdorp, A.D., Daan, N., Dekker, W., Poos, J.J., Van Densen, W.L.T., 2007. Sustainable use of flatfish resources: Addressing the credibility crisis in mixed fisheries management. J. Sea. Res. 57, 114-125.

Rochet, M-J., Trenkel, V. M., 2005. Factors for the variability of discards: assumptions and field evidence. Can. J. Fish. Aquat. Sci. 62, 224-235.

Sparholt, H., 1990. An estimate of the total biomass of fish in the North Sea. J. Cons. int. Explor. Mer: 46: 200-210.

Stratoudakis, Y., Fryer, R. J., Cook, R. M., Pierce, G. J., Coull, K. A., 2001. Fish Bycatch and discarding in Nephrops trawlers in the Firth of Clyde (west of Scotland). Aquat. Liv. Res. 14, 283291.

Sullivan, L. M., D’Agostino, R. B., 1992. Robustness of the t test applied to data distorted from normality by floor effects. J. Dent. Res. 71, 1938-1943.

Van Beek, F.A., van Leeuwen, P.I., Rijnsdorp, A.D., 1990. On the survival of plaice and sole discards in the otter-trawl and beam-trawl fisheries in the North Sea. Neth. J. Sea. Res. 26, 151160.

Van Beek, F.A., Rijnsdorp, A.D., van Leeuwen, P.I., 1981. Results of mesh selection experiments on North Sea plaice with a commercial beam trawler in 1981. ICES C.M. 1981/B:32.

Van Keeken, O.A., Van Hoppe, M, Grift, R. E., Rijnsdorp, A. D., 2007. Changes in the spatial distribution of North Sea plaice (Pleuronectes platessa) and implications for fisheries management. J. Sea Res. 57, 187-197.

Votier, S. C., Furness, R. W., Bearhop S., Crane, J. E., Caldow, R.W.G, Catry, P., Ensor, K., Hamer, K.C., Hudson, A.W., Kalmbach, E., Klomp, N.I., Pfeiffer, S., Phillips, R.A., Prieto, I., 
Thompson, D.R., 2004. Changes in fisheries discard rates and seabird communities. Nature 427, 727-730.

Zuur, A.F., Ieno, E.N., Walker, N.J., Saveliev, A.A., Smith, G.M., 2009. Mixed effects models and extensions in ecology with R. Springer, New York 
Table 1. General information for the three mesh size categories per haul. Standard deviations are indicated in brackets.

\begin{tabular}{lccc}
\hline & $80-99 \mathrm{~mm}$ & $100-119 \mathrm{~mm}$ & \multicolumn{1}{c}{ (20 mm } \\
\hline Years (no.) & 5 & 13 & 33 \\
Vessels (no.) & 9 & $639(219)$ & $6.3(1.4)$ \\
Mean engine power (hp) & $533(290)$ & $5.9(1.4)$ & 71 \\
Mean haul duration (hrs) & $6.5(1.3)$ & 22 & 423 \\
Trips (no.) & 10 & 139 & 230 \\
Hauls total (no.) & 57 & 63 & 129 \\
Hauls without plaice (no.) & 1 & 63 & 187 \\
Hauls with discard (no.) & 53 & $64^{\mathrm{a}}$ & \\
Hauls with plaice landings (no.) & 56 & &
\end{tabular}

${ }^{\mathrm{a}}$ No length measurements in 15 hauls 
Table 2. Means for different discards and landings categories per haul. Confidence limits (95\%) are indicated in brackets. Asterisks in the first, second and third columns represent the significance levels from the two-sample t-tests for the comparisons between $80-99 \mathrm{~mm}$ and 100-119 $\mathrm{mm}, 100$ $119 \mathrm{~mm}$ and $\geq 120 \mathrm{~mm}$, and $80-99 \mathrm{~mm}$ and $\geq 120 \mathrm{~mm}$ mesh size category respectively.

\begin{tabular}{lccr}
\hline & $80-99 \mathrm{~mm}$ & $100-119 \mathrm{~mm}$ & $\geq 120 \mathrm{~mm}$ \\
\hline Discard (no./hour) & $146.0(102.3-189.7)^{* * *}$ & $47.2(23.8-70.6)^{* * *}$ & $5.4(3.5-7.3)^{* * *}$ \\
Landed (no./hour) & $70.9(56.7-85.1)^{\mathrm{ns}}$ & $66.1(33.7-98.5)^{\mathrm{ns}}$ & $68.2(49.1-87.3)^{\mathrm{ns}}$ \\
Discard proportion (no.) & $0.546(0.481-0.611)^{* * *}$ & $0.177(0.119-0.235)^{* * *}$ & $0.069(0.051-0.087)^{* * *}$ \\
Discard length (cm) & $23.3(22.3-24.3)^{* *}$ & $25.0(24.8-25.2)^{* * *}$ & $26.0(25.7-26.3)^{* * *}$ \\
Landed length (cm) & $31.5(30.8-32.2)^{\mathrm{ns}}$ & $32.8(30.2-35.5)^{\mathrm{ns}}$ & $33.4(32.9-33.9)^{* * *}$ \\
Discard proportion $<\mathrm{MLS}$ & $0.960(0.938-0.982)^{* *}$ & $0.892(0.848-0.936)^{* * *}$ & $0.689(0.629-0.749)^{* * *}$ \\
Discard proportion 23-24 cm & $0.260(0.215-0.305)^{\mathrm{ns}}$ & $0.270(0.224-0.316)^{* * *}$ & $0.147(0.109-0.185)^{* * *}$ \\
Discard proportion 25-26 cm & $0.279(0.216-0.342)^{* * *}$ & $0.588(0.540-0.636)^{* *}$ & $0.486(0.432-0.540)^{* * *}$ \\
Discard proportion 27-28 cm & $0.029(0.017-0.041)^{* * *}$ & $0.083(0.057-0.109)^{* * *}$ & $0.212(0.165-0.259)^{* * * *}$ \\
\hline
\end{tabular}

ns: non significant $(\mathrm{P} \geq 0.05)$

$* *: \mathrm{P}<0.01$

$* * *: \mathrm{P}<0.001$ 
Table 3. Final model results estimated by the GAM model. SE indicates standard error.

\begin{tabular}{lcccc}
\hline Parameter & Estimate & SE & Z-value & P-value \\
\hline Categorical terms & & & & \\
Mesh size category $80-99 \mathrm{~mm}$ & -3.25 & 1.11 & -2.95 & 0.003 \\
Mesh size category $100-119 \mathrm{~mm}$ & -3.75 & 1.08 & -3.46 & $<0.001$ \\
Mesh size category $\geq 120 \mathrm{~mm}$ & -3.82 & 1.07 & -3.57 & $<0.001$ \\
\hline Parameter & Estimate & SE & Chi squared & \multirow{2}{*}{ P-value } \\
\hline Smooth terms & & & & \\
S(Longitude, latitude) & 18.5 & 18.8 & 716.3 & $<0.001$ \\
\hline
\end{tabular}

Number data points: 619

Dispersion parameter: 0.48

AIC : 3012 


\section{Figure captions:}

Fig. 1. Geographical indication of place for individual hauls (midpoint of tow).

Fig. 2. Selection curves for three relevant mesh size categories. The MLS is indicated by the vertical line.

Fig. 3. Geographical indication of the relative numbers discarded under MLS per haul predicted by the GAM model. The surface and contour lines describe the effect of the two dimensional smoothing function on the geographical coordinates. Red area indicates highest discard rate. Only areas covered by observations are indicated. 


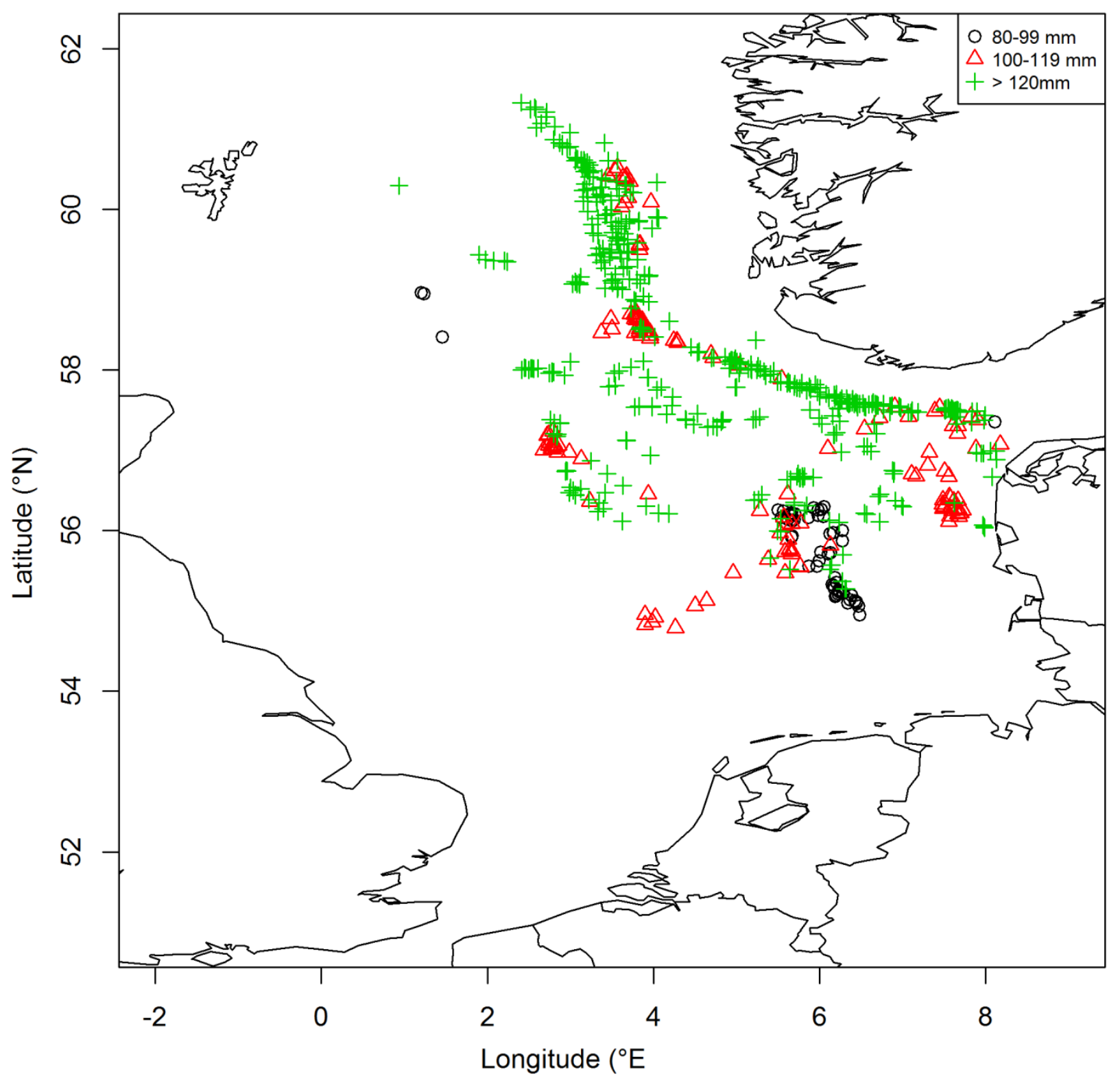

Fig. 1. 


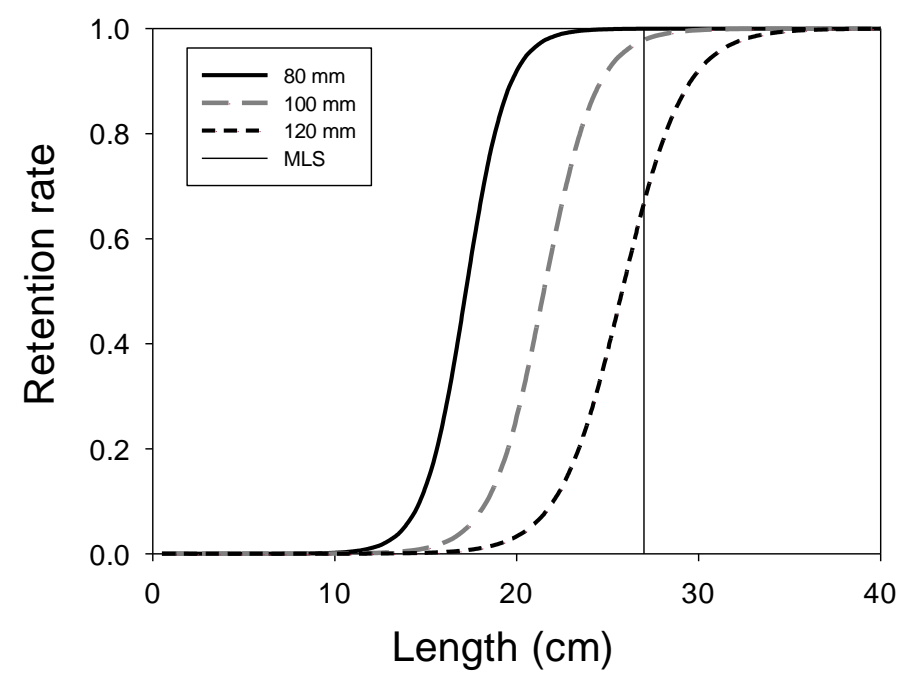

Fig. 2. 


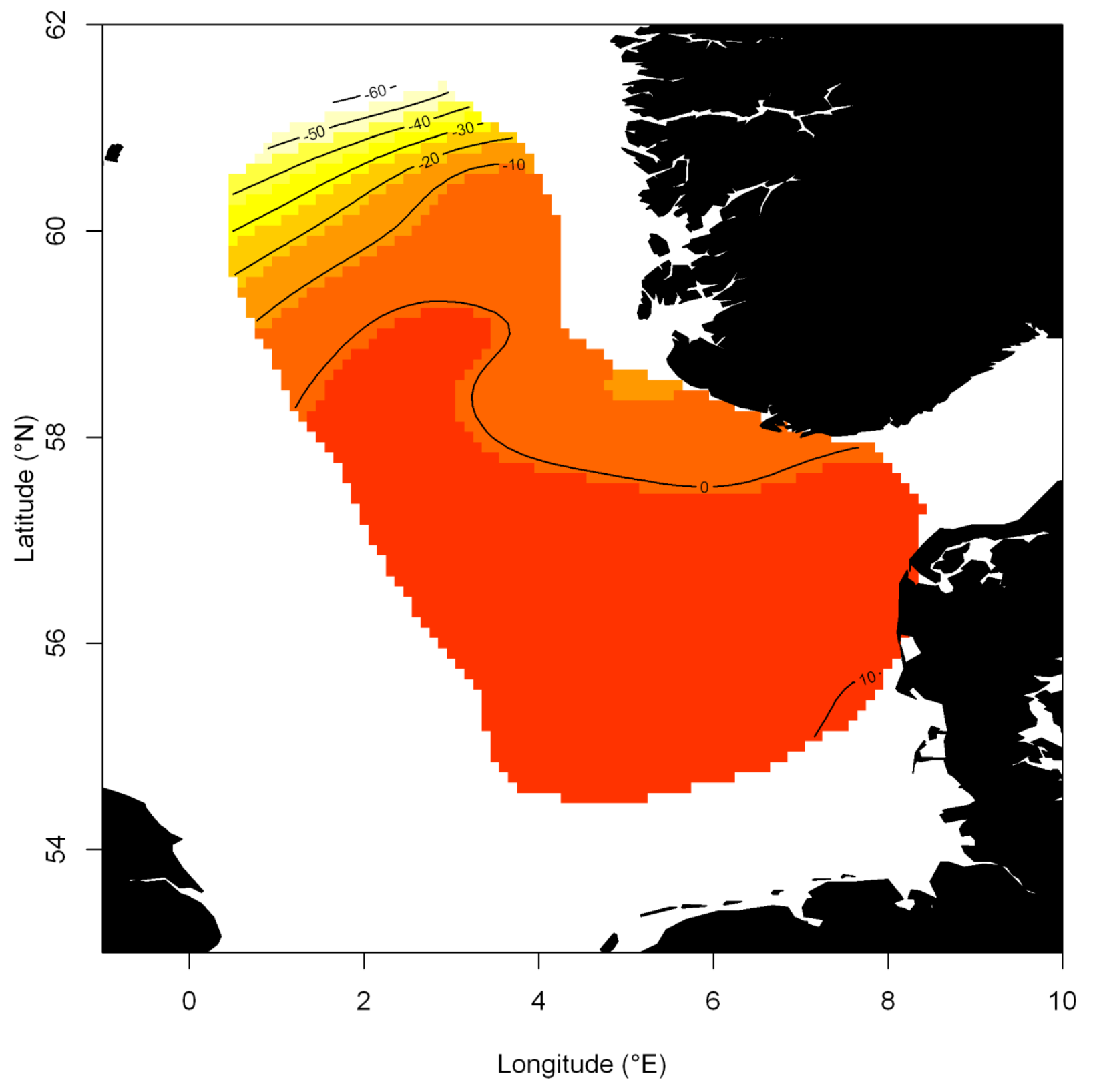

Fig. 3. 